\title{
First record of Cocculinella (Mollusca, Gastropoda, Cocculiniformia) from the Lower Pleistocene of Southern Italy with the description of two new species
}

\author{
Bruno DELL'ANGELO \\ Via Santelia 55/12A, I-16153 Genova (Italy) \\ bruno.dellangelo@chitons.it \\ Maurizio SOSSO \\ Via Bengasi 4/4, I-16153 Genova (Italy) \\ maurizio.sosso@tele2.it \\ Antonio BONFITTO \\ Via Selmi 3, I-40126 Bologna (Italy) \\ antonio.bonfitto@unibo.it
}

Dipartimento di Biologia evoluzionistica e sperimentale,

KEY WORDS

Mollusca,

Gastropoda,

Cocculiniformia,

Cocculinellidae,

Pleistocene,

Mediteranean basin,

Italy,

new species.
Dell'Angelo B., Sosso M. \& Bonfitto A. 2011. - First record of Cocculinella (Mollusca, Gastropoda, Cocculiniformia) from the Lower Pleistocene of Southern Italy with the description of two new species. Geodiversitas 33 (4): 739-746. DOI: 10.5252/g2011n4a9.

\section{ABSTRACT}

Cocculinella freti n. sp., from Archi and Valanidi (Reggio Calabria) and Cocculinella bertolasoi n. sp., from Valanidi (Reggio Calabria) and Capo Milazzo (Messina, Sicily), are described from three southern Italian Lower Pleistocene outcrops (bathyal assemblages). No species of the genus Cocculinella Thiele, 1909 is known from the Atlantic and the Mediterranean, whereas three living species are known from the Indo-Pacific. Very little, mostly questionable information is known on fossil species of the genus. The present report is the first unequivocal fossil record of Cocculinella, allowing the stratigraphic and biogeographic range of the genus to be extended to the Lower Pleistocene of the Mediterranean.

RÉSUMÉ

Première occurence de Cocculinella (Mollusca, Gastropoda, Cocculiniformia) du Pléistocène inférieur du sud de l'Italie, avec la description de deux nouvelles espèces.

Cocculinella freti n. sp. et Cocculinella bertolasoi $\mathrm{n}$. sp. sont décrites de trois affleurements du Pléistocène inférieur (biocénoses bathyale) du sud de l'Italie. 


\author{
MOTS CLÉS \\ Mollusca, \\ Gastropoda, \\ Cocculiniformia, \\ Cocculinellidae, \\ Pléistocene, \\ bassin Méditerranéen, \\ Italie, \\ espèces nouvelles.
}

La première espèce a été trouvée dans des échantillons d'Archi et Valanidi (province de Reggio Calabria), la deuxième dans des échantillons de Valanidi et de Capo Milazzo (province de Messina, Sicile). Le genre Cocculinella Thiele, 1909 n’est pas connu dans les faunes modernes de la mer Méditerranée et de l'océan Atlantique, alors que trois espèces vivantes sont signalées dans les océans Indien et Pacifique. Dans le même temps, les informations sur les espèces fossiles sont rares et incertaines. Les deux espèces nouvelles représentent donc la première occurrence de ce genre dans les faunes fossiles et nous permettent d'étendre sa présence au Pléistocène inférieur du sud de l'Italie.

\section{INTRODUCTION}

The Cocculinellidae Moskalev, 1971 are a family of symmetrical limpets, with a narrowly elliptical aperture and subcentral apex (Haszprunar 1998). The radula is highly modified and highly diagnostic (Moskalev 1976; Marshall 1983, 1985).

A single genus, Cocculinella Thiele, 1909, is known for the family, including three species: Cocculinella coercita Hedley, 1907, from Australia, C. osteophila Marshall, 1983, from New Zealand and C. minutissima (Smith, 1904), type species of the genus, from the Andaman Islands (Indian Ocean) (Marshall 1983, 1985; Haszprunar 1988, 1998). Another species, C. kopua Marshall, 1983, described from a single dead shell from New Zealand, was re-considered, by Marshall (1985), as a possible synonym of C. osteophila. Two other Australian species, C. tasmanica (May, 1919) and C. mayi Finlay, 1926 are recorded in some web-databases, such as "A Guide to the Marine Molluscs of Tasmania" (http://www. molluscsoftasmania.net [2010]) or OBIS (Ocean Biogeographic Information System); these species are not considered belonging to Cocculinella by Haszprunar (1998), and are refered to Tectisumen Finlay, 1926, a genus attributed to family Lepetellidae Dall, 1882 by other authors (e.g., Keen 1960; Moskalev 1978).

All cocculinellid species live and feed on fish bones.

This paper focuses on the finding of four fossil shells of Cocculinella in three Lower Pleistocene out- crops in southern Italy, attributed to two different species, described as new. No living species of this genus are known in the Mediterranean Sea and in the Atlantic Ocean, and there is very little information on fossil species, and so the description of the these new species is particularly important for the knowledge of the stratigraphic and biogeographic distribution of the genus.

\section{MATERIAL AND METHODS}

The shells were found by Stefano Palazzi in two Lower Pleistocene outcrops in Southern Italy, Archi (Reggio Calabria, 1 shell) and Valanidi (Reggio Calabria, 2 specimens), and by Luca Bertolaso at Capo Milazzo, Sicily (Fig. 1).

Archi is a clay quarry, locally known as "Fornace Aloi", situated in the northern suburbs of Reggio Calabria, with a rich lower Pleistocene fauna, that can be attributed to a bathyal paleoenvironment, 500 to 1000 m deep (Guadagno et al. 1979; Di Geronimo et al. 1997). The molluscs have been listed by Micali \& Villari (1986), Rindone \& Vazzana (1989) and Di Geronimo et al. (1997).

Valanidi is a clay quarry, near Bovetto (Reggio Calabria), with a rich lower Pleistocene fauna, that can be attributed to a bathyal biocoenoses. This outcrop has scarcely been reported in the literature (Seguenza 1879; Barrier 1987), and there is no published list of the molluscs occuring there, apart from isolated reports of some rare species (e.g., Vazzana 1996). 


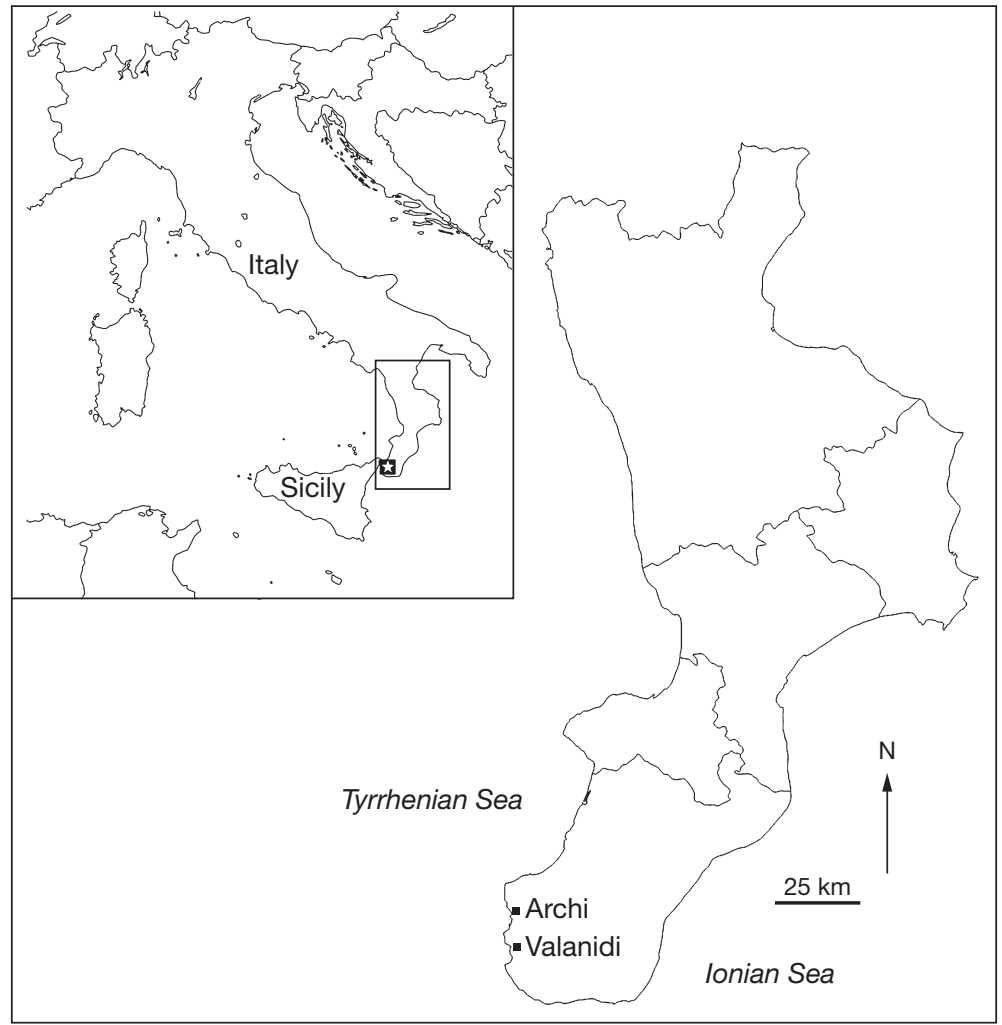

FIG. 1. - Location of the outcrops in Southern Italy, where Cocculinella Thiele, 1909 species were found.

The Neogene sedimentary sequence at Capo Milazzo (Messina, NE Sicily) is well known (Ruggieri \& Greco 1965; Fois 1990). The Cocculinella shell was found in bathyal deposits of Lower Pleistocene age outcropping at Punta Lazzi, which can be attributed to a bathyal biocoenoses (Palazzi \& Villari 1996). There have been several papers on Capo Milazzo molluscs (Gignoux 1913; Mars 1956), and the PlioPleistocene bathyal molluscan assemblages are well documented (Palazzi \& Villari 1996).

SEM micrographs were taken using a JEOL model JSM-5200.

\section{ABBREVIATIONS}

AL anterior length (distance from the posterior extremity of protoconch to the anterior end of teleoconch parallel to apertural plain);

$\mathrm{H}$ shell height;
L shell length;

W shell width.

Repository

BD Bruno Dell'Angelo collection, Genova, Italy; MZB Museo di Zoologia dell'Università di Bologna, Italy.

\section{SYSTEMATICS}

Superorder COCCULINIFORMIA

Superfamily LEPETELLOIDEA

Family CoCCulinelLidAe Moskalev, 1971

Genus Cocculinella Thiele, 1909

TYPe SPECIES. — Acmaea minutissima Smith, 1904; Recent, Andaman Islands, Indian Ocean, 238-457 m. 
TABLE 1. - Measurements (in $\mathrm{mm}$ ) of Cocculinella freti $\mathrm{n}$. sp. shells.

\begin{tabular}{lcccccccc}
\hline Cocculinella freti n. sp. & $\mathbf{L}$ & $\mathbf{W}$ & $\mathbf{H}$ & $\mathbf{A L}$ & $\mathbf{L} / \mathbf{W}$ & $\mathbf{L} / \mathbf{H}$ & L/AL & W/H \\
\hline Holotype (Archi) & 3.03 & 1.04 & 1.38 & 1.77 & 2.91 & 2.20 & 1.71 & 0.75 \\
Paratype (Valanidi) & 5.21 & 1.39 & 2.41 & 2.68 & 3.75 & 2.16 & 1.94 & 0.58 \\
\hline
\end{tabular}

TABLE 2. - Measurements (in mm) of Cocculinella bertolasoi $\mathrm{n}$. sp. shells.

\begin{tabular}{lcccccccc}
\hline Cocculinella bertolasoi n. sp. & L & W & H & AL & L/W & L/H & L/AL & W/H \\
\hline Holotype (Valanidi) & 3.87 & 1.62 & 1.92 & 1.95 & 2.39 & 2.02 & 1.98 & 0.84 \\
Paratype (Capo Milazzo) & 2.03 & 1 & 1.19 & 1.22 & 2.03 & 1.71 & 1.66 & 0.84 \\
\hline
\end{tabular}

\section{Cocculinella freti $\mathrm{n}$. sp.} (Fig. 2A-F)

TYPe MATERiAl. - Holotype: MZB 45691, shell from Archi (Fig. 2A, B, D-F). Paratype: BD, shell from Valanidi (Fig. 2C).

ETYMology. - From the latin world "fretum", "strait" (of Messina), alluding to the occurrence at two outcrops near the Calabrian coast of the Messina Strait.

Type Locality and horizon. - Archi, Reggio Calabria Province, Southern Italy, Lower Pleistocene.

MeAsurements. - see Table 1.

\section{DESCRIPTION}

Shell patelliform, up to $5.21 \mathrm{~mm}$ long $(3.03 \mathrm{~mm}$ the holotype), thin and fragile. Aperture narrowly elliptical, ends evenly rounded, sides subparallel and very shallowly rounded, slightly convex from side to side so that only the center contacts a flat surface. Spire depressed-conical, apex slightly behind the centre, anterior slope profile slightly convex, posterior slope profile shallowly concave, anterior and posterior slope areas regularly connected with lateral areas, posterior outline subangular. Protoconch clearly demarcated, $285 \mu \mathrm{m}$ long and $188 \mu \mathrm{m}$ wide in the holotype, of about one whorl, tip of apical fold perfectly fused behind the apertural rim. Teleoconch with only fine collabral growth lines.

\section{REMARKS}

The paratype from Valanidi has the same narrow and elongate general shape as the holotype. The protoconch is partially eroded, so it was possible only to measure the length, $310 \mu \mathrm{m}$, which is closely accordant with that of the holotype $(285 \mu \mathrm{m})$.

DisTRIBUTION

Cocculinella freti $\mathrm{n}$. sp. is only known from the lower Pleistocene of Archi and Valanidi, Reggio Calabria Province, Southern Italy.

\section{Cocculinella bertolasoi $\mathrm{n}$. sp.}

(Fig. 2G-L)

Type MATERIAL. - Holotype: MZB 45692, shell from Valanidi (Figs 2G, H, J-L). Paratype: BD, shell from Capo Milazzo (Fig. 2I).

ETYMOLOGY. - The specific name honours our friend Luca Bertolaso (Reggio Emilia), who collected part of the material here presented and made it available to the authors.

Type LOCALITY. - Valanidi, Reggio Calabria Province, Southern Italy.

TyPe STAGE. - Lower Pleistocene.

Measurements. — see Table 2.

\section{DESCRIPTION}

Shell patelliform, up to $3.87 \mathrm{~mm}$ long (the holotype), thin and fragile. Aperture narrowly elliptical, ends evenly rounded, sides subparallel and very shallowly rounded, slightly convex from side to side so that only the center contacts a flat surface. Spire depressed-conical, apex slightly behind the 


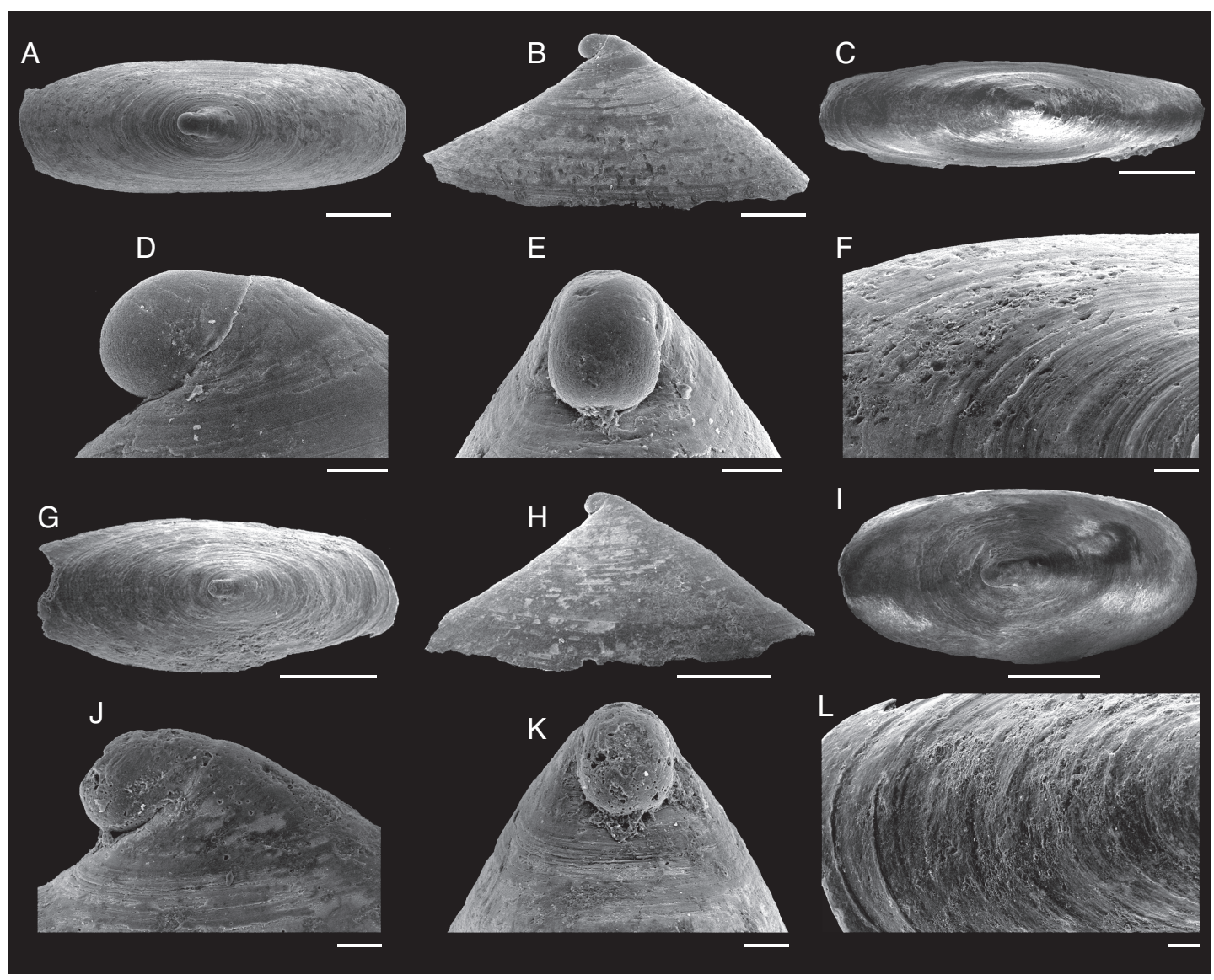

FIG. 2. - Lower Pleistocene Cocculinella Thiele, 1909 species: A-F, Cocculinella freti n. sp.; A, B, D-F, holotype (MZB 45691) from Archi (Reggio Calabria Province) in dorsal (A) and lateral (B) views; D, E, protoconch; F, teleoconch; C, paratype from Valanidi (Reggio Calabria Province), dorsal view, not coated; G-L, Cocculinella bertolasoi n. sp.; G, H, J-L, holotype (MZB 45692), from Valanidi (Reggio Calabria Province) in dorsal (G) and lateral (H) views; J, K, protoconch; L, teleoconch; I, paratype from Capo Milazzo (Messina Province, Sicily), not coated. Scale bars: A, B, I, $500 \mu \mathrm{m} ; \mathrm{C}, \mathrm{G}, \mathrm{H}, 1 \mathrm{~mm}$; D-F, J-L, $100 \mu \mathrm{m}$.

centre, anterior slope profile slightly convex, posterior slope profile practically straight or shallowly concave, anterior and posterior slope areas regularly connected with lateral areas, posterior outline regularly rounded. Protoconch clearly demarcated, $335 \mu \mathrm{m}$ long and $220 \mu \mathrm{m}$ wide in the holotype, of about one whorl, tip of apical fold perfectly fused behind the apertural rim. Teleoconch with only fine collabral growth lines.

\section{REMARKS}

The paratype from Capo Milazzo has the same general shape as the holotype. Cocculinella bertolasoi n. sp. differs from $C$. freti n. sp. in general shape, more narrow and elongate in $C$. freti $\mathrm{n}$. sp. (L/W 2.913.75 in $C$. freti n. sp. vs 2.03-2.39 in C. bertolasoi n. sp.; W/H $0.58-0.75$ in $C$. freti $n$. sp. vs 0.84 in C. bertolasoi n. sp.) and in having a more globose and larger protoconch $(285 \times 188 \mu \mathrm{m}$ in C. freti n. sp. vs $335 \times 220 \mu \mathrm{m}$ in C. bertolasoi n. sp.).

\section{DISTRIBUTION}

Cocculinella bertolasoi $\mathrm{n}$. sp. is only known from the lower Pleistocene of Valanidi (Reggio Calabria Province, Calabria) and Capo Milazzo (Messina Province, Sicily), Southern Italy. 
TABLE 3. - Cocculinella Thiele, 1909 species, published data.

\begin{tabular}{lccccccc}
\hline & \multicolumn{3}{c}{ Protoconch } & & & & \\
& shells & size $(\boldsymbol{\mu m})$ & $\mathbf{L}(\mathbf{m m})$ & L/W & L/H & L/AL & W/H \\
\hline C. minutissima (Smith, 1904) & 1 & - & 3.5 & 2.63 & 3.5 & - & 1.33 \\
C. osteophila Marshall, 1983 & 6 & $233 \times 150$ & $1.13-2.30$ & $1.82-2.33$ & $3.12-4.83$ & $1.41-1.64$ & $1.41-1.72$ \\
C. coercita Hedley, 1907 & 6 & - & $2.60-6.60$ & $2.20-4.12$ & $2.60-3.77$ & $1.57-1.94$ & $0.80-1.24$ \\
C. freti n. sp. & 2 & $285 \times 188$ & $3.03-5.21$ & $2.91-3.75$ & $2.16-2.20$ & $1.71-1.94$ & $0.58-0.75$ \\
C. bertolasoi n. sp. & 2 & $335 \times 220$ & $2.03-3.87$ & $2.03-2.39$ & $1.71-2.02$ & $1.66-1.98$ & 0.84 \\
\hline
\end{tabular}

\section{DISCUSSION}

There are few taxonomically useful shell characters that can be used to separate the species of the family Cocculinellidae. All the known species (1.13-6.6 mm long) have a narrowly elliptical aperture and subcentral apex, and exhibit a weak, concentric sculpture. The protoconch has a fused tip and has no significant sculpture. The radula is greatly modified and highly diagnostic (Haszprunar 1998). The present species are attributed to the genus Cocculinella on the basis of the close similarity of the shell to those of the known Recent Cocculinella species, C. minutissima from the Indian Ocean, and C. coercita and $C$. osteophila from the south-western Pacicific Ocean. Very few data are available on the variability of these species. All available morphometric data is tabulated here (Table 3).

Two Cocculinella species were reported by VeraPeláez et al. (1995) from the Pliocene of Estepona: C. cf. minutissima (Smith, 1904) and C. compressiuscula (Karsten, 1849), described from the Miocene of the North Sea basin. These were simply names in a list of molluscs, with no other data or figures, and were not reported by Landau et al. (2003) in their paper on Estepona Vetigastropoda. Patella compressiuscula Karsten, 1849 is probably referable to Lepetella. B. Landau (pers. com.) has informed us that no species referable to Cocculinella has been found in the Estepona Pliocene, so it is better to ignore these reports.

Cocculinella salisburyensis Ludbrook, 1956 was described from the Pliocene of South Australia, but the only available specimen (holotype) has a much more strongly posterior apex that any Recent Cocculinella and is very doubtfully referable to this genus (Marshall 1983: 142).
The present report is thus the first fossil record of Cocculinella, allowing the stratigraphic and biogeographic range of the genus to be extended to the Lower Pleistocene of the Mediterranean.

An Indo-Pacific affinity for some molluscan taxa from the Plio-Pleistocene bathyal deposits of the Mediterranean basin is fairly well known (e.g., La Perna et al. [2004] for the nuculanid genus Jupiteria Bellardi, 1875 and Zealeda Marwick, 1924; La Perna [2007] for the nuculanid genus Deminucula Iredale, 1931). This affinity can be explained by the faunal continuity between the two areas, as part of the Tethys Realm, until the Early Miocene (Popov 1993; Harzhauser et al. 2002, 2007), when the formation of a landbridge between the Eurasia and Arabian plates, in the late Burdigalian (approximately $19 \mathrm{Ma}$ ), separated western (Proto Mediterranean Atlantic Region) and eastern (Proto Indo-West-Pacific Region) parts (Rögl 1998, 1999; Harzhauser et al. 2007). However, as regard to the genus Cocculinella, the hypothesis of a fragmentation of the area of origin can only be considered assuming that the taxon is much older and with a wider distribution than the one appearing in the fossil record.

Other members of the superorder Cocculiniformia have a fossil distribution not so erratic as suggested by the occurrence of Cocculinella; in the genus Cocculina Dall, 1882 (family Cocculinidae, superfamily Cocculinoidea), Cocculina miocaenica Boettger, 1901 is known from the Paratethys (Romania, Poland) and North Sea basin (The Netherlands) Miocene, Cocculina adunca (Jeffreys, 1883) from the Spanish and Italian Early Pliocene, Cocculina dittmeri (Anderson, 1964) from German Miocene and Cocculina unica Bałuk, 2006 from the Paratethys (Poland) Miocene (Anderson 1964; Janssen 1984; Landau et al. 2003; Bałuk 2006). 


\section{Acknowledgements}

We wish to thank Luca Bertolaso (Reggio Emilia, Italy) and Stefano Palazzi (Modena, Italy) for the material studied here, Angelo Vazzana (Reggio Emilia) for information on the Valanidi outcrop, Bernard Landau (Albufeira, Portugal) for his help regarding the supposed fossil Cocculinella reports from Spain. Karen Gowlett-Holmes (Tasmania, Australia), Bruce A. Marshall (Museum of New Zealand Te Papa Tongarewa, Wellington, New Zealand), Robert Hamilton-Bruce, Thierry Laperousaz and Ben McHenry (South Australian Museum, Adelaide, Australia), Lisa-ann Gershwin (Queen Victoria Museum and Art Gallery, Tasmania, Australia) helped us with bibliography and information on living Australian and New Zealand species. We thank Rafael La Perna (Università di Bari, Italy), Mathias Harzhauser (Natural History Museum, Vienna) and Annemarie Ohler (Muséum national d'Histoire naturelle, Paris) for their useful comments and contructive criticism on an earlier version of the manuscript.

\section{REFERENCES}

Anderson H. J. 1964. - Die miocäne Reinbek-Stufe in Nord- und Westdeutschland und ihre MolluskenFauna. Fortschritte in der Geologie von Rheinland und Westfalen 14: 31-368.

BAŁUK W. 2006. - Middle Miocene (Badenian) gastropods from Korytnica, Poland; Part V Addenda et Corrigenda ad Prosobranchia. Acta Geologica Polonica 56: 177-220.

BARRIER P. 1987. - Stratigraphie des dépôts pliocènes et quaternaires du Détroit de Messine, in BARRIER P., Di GERONimo I. \& MonTEnANT C. (eds), Le Détroit de Messine (Italie), Évolution tectono-sédimentaire récente (Pliocène et Quaternaire) et environnement actuel. Documents et travaux de l'Institut Géologique Albert de Lapparent 11: 59-81.

Di Geronimo I., D’Atri A., La Perna R., Rosso A., SANFILIPPO R. \& Violanti D. 1997. - The Pleistocene bathyal section of Archi (Southern Italy). Bollettino della Società Paleontologica Italiana 36: 189-212.

FoIs E. 1990. - La successione neogenica di Capo Milazzo (Sicilia Nord-Orientale). Rivista Italiana di Paleontologia e Stratigrafia 95: 397-440.

Gignoux M. 1913. — Les formations marines pliocènes et quaternaires de l'Italie du Sud et de la Sicile. Thèse, faculté des Sciences de l'Université de Lyon, Lyon: xxiv+694, 21 pls.

Grove S. 2010 - A Guide to the Marine Molluscs of Tasmania. http://www.molluscsoftasmania.net/Genus\%20 pages/Cocculinella.html (last access 3/07/2010).

Guadagno M., Taddei Ruggiero E., De Blasio I., Placella B. \& Sgarrella F. 1979. - La sezione pleistocenica di Archi (RC). Bollettino della Società dei Naturalisti in Napoli 88: 1-29.

Harzhauser M., Piller W. E. \& Steininger F. F. 2002. - Circum-Mediterranean Oligo-Miocene biogeographic evolution - the gastropods' point of view. Palaeogeography, Palaeoclimatology, Palaeoecology 183: 103-133.

Harzhauser M., Kroh A., Mandic O., Piller W. E., Göhlich U., Reuter M. \& Berning B. 2007. Biogeographic responses to geodynamics: A key study all around the Oligo-Miocene Tethyan Seaway. Zoologischer Anzeiger-Journal of Comparative Zoology 246: 241-256.

HaszPrunar G. 1988. — Anatomy and relationships of the boone-feeding limpets, Cocculinella minutissima (Smith) and Osteopelta mirabilis Marshall (Archaeogastropoda). Journal of Molluscan Studies 54: 1-20.

HaszPrunar G. 1998. — Superorder Cocculiniformia, in Beesley P. L., Ross G. J. B. \& Wells A. (eds), Mollusca: The Southern Synthesis. Fauna of Australia. Vol. 5. CSIRO Publishing, Melbourne, Part B: 653-664.

JANSSEN A. W. 1984. - Mollusken uit het Mioceen van Winterswijk-Miste. Een inventarisatie met beschrijvingen en afbeeldingen van alle aangetroffen soorten. Koninklijke Nederlandse Natuurhistorische Vereniging, Amsterdam, $451 \mathrm{p}$.

La Perna R. 2007. - The deep-water protobranch Deminucula (Bivalvia) in the Mediterranean PlioPleistocene and the contribution of palaeobiogeography to taxonomy. Bollettino Malacologico 43: 3-12.

la Perna R., Ceregato A. \& Tabanelli C. 2004. Mediterranean Pliocene protobranchs: the genera Jupiteria Bellardi, 1875, Ledella Verrill \& Bush, 1897 and Zealeda Marwick, 1924 (Mollusca, Bivalvia). Bollettino Malacologico 40: 25-36.

Landau B., Marquet R. \& Grigis M. 2003. - The Early Pliocene Gastropoda (Mollusca) of Estepona, southern Spain. Palaeontos 3: 1-87.

MARS M. 1956. - Faunes malacologiques du Pliocène et du Quaternaire de Milazzo (Sicile). Bulletin du Muséum d'Histoire naturelle de Marseille 16: 33-52.

Marshall B. A. 1983. - The family Cocculinellidae (Mollusca: Gastropoda) in New Zealand. National Museum of New Zealand Records 2: 139-143.

Marshall B. A. 1985. - Recent and Tertiary Cocculinidae and Pseudococculinidae (Mollusca: Gastropoda) from New Zealand and New South Wales. New Zealand Journal of Zoology 12: 505-546.

Micali P. \& Villari A. 1986. - Riscoperta di Calliostoma sayanus (G. Seguenza, 1873) e considerazioni 
sul Pleistocene di Archi (RC). Bollettino Malacologico 22: 267-272.

MOSKALEV L. I. 1976. - [On the generic classification in Cocculinidae (Gastropoda, Prosobranchia)]. Trudy Instituta Okeanologii, Akademiya Nauk SSSR 99: 5970 (in Russian).

MOSKALEV L. I. 1978. - [Lepetellidae (Gastropoda, Prosobranchia) and related forms]. Trudy Instituta Okeanologii, Akademiya Nauk SSSR 113: 132-146 (in Russian).

OBIS Indo-Pacific Molluscan Database. - http:// clade.ansp.org/obis/ (last access 03/07/2010).

PALAZZI S. \& Villari A. 1996. — Malacofaune batiali Plio-Pleistoceniche del Messinese. 2: Capo Milazzo. Naturalista siciliano (4) 20: 237-279.

PopOV S. V. 1993. - Zoogeography of the Late Eocene basins of western Eurasia based on bivalve mollusks. Stratigraphy and Geological Correlation 2/6: 103-118.

Rindone V. \& Vazzana A. 1989. - Alcune specie di molluschi delle argille batiali del piano Siciliano (Pleistocene inf.) della cava di Archi (Reggio Calabria). Bollettino Malacologico 25: 233-240.

RÖGL F. 1998. — Palaeogeographic considerations for
Mediterranean and Paratethys seaways (Oligocene to Miocene). Annalen des Naturhistorischen Museums in Wien 99: 279-310.

RÖGL F. 1999. - Circum-Mediterranean Miocene paleogeography, in RösSNER G. \& HEISSIG K. (eds), The Miocene Land Mammals of Europe. Dr Fritz Pfeil Verlag, Munich: 39-48.

RugGieri G. \& Greco A. 1965. - Studi geologici e paleontologici su Capo Milazzo con particolare riguardo al Milazziano. Geologica Romana 4: 41-48, pls 1-11.

SeguenZa G. 1879. - Le formazioni terziarie nella provincia di Reggio (Calabria). Reale Accademia dei Lincei, Memorie della Classe di scienze fisiche, matematiche e naturali 6: 1-446.

VAZZANA A. 1996. - Malacofauna batiale del Pleistocene inferiore del Vallone Catrica (Reggio Calabria, Italia). Bollettino Malacologico 31: 143-162 (dated 1995, published 1996).

Vera-Peláez J. L., Lozano-Francisco M. C., MuñizSolís R., Gili C., Martinell J., Domènech R., PalmQuist P. \& Guerra-MerChán A. 1995. - Estudio preliminar de la malacofauna del Plioceno de Estepona (Málaga, España). Iberus 13: 93-117.

Submitted on 30 March 2010; accepted on 17 December 2010. 